Historic, Archive Document

Do not assume content reflects current scientific knowledge, policies, or practices. 




\section{PRICE LIST AND DESCRIPTION}

Abbreviations: C., siginifies Cactus; $D_{4}$, Decorative H. C., Hybrid Cactus

H. D., Hybrid Decorative

\section{Strong, Field-Grown Roots}

ALICE WHITTIER H. C. - Large flower, color primrose yellow. Roots, $\$ 1.00$.

AZTEC GLORY, D.-Picric yellow (lemon yellow), large flowers. Roots, $\$ 4.00$.

ALICE GREEN, D. - Pleasing shade of orange, Roots, $\$ 1.00$.

ANDREAS HOFER, C., - One of the best imported dahlias. Color is light pink, with salmonrose suffusion. Roots, $\$ 1.50$.

A. O. KENNEY, D. - Large blooms of perfect form and great depth carried on good stems. Color a rich bronze buff with center tinted bronze. Roots, $\$ 4.00$.

BARBARA REDFERN, D. - An immense flower in size and great depth, very free blooming, with good stiff stems. Color is a blending of old rose and gold. Roots, $\$ 2.00$.

BROCKTON BEAUTY, D. - Color is pink and lavender, shading to a creamy white center with reverse of petals light lavendar. Roots, $\$ 2.00$. CORINGA, H. D. - Beautiful Copper orange dahlia, one of the best of its color. Roots, $\$ 3.50$.

CHEMAR'S MASTERPIECE C. - A huge incurved cactus flower of orchid pink or soft orchid coloring. Extra large flowers. Roots, $\$ 2.00$.

CONQUISTADOR, H. C. - Soft, creamy yellow shading to a pink at the base of the petals. Roots, $\$ 4.00$.

CHEMAR'S 2406 - A very large decorative. Color a rich red. Roots, $\$ 2.50$.

CLANSMAN, D. - Beautiful apricot orange, center darkening to Jasper pink. Roots, $\$ 1.50$.

COL. CHAS. A. LINDBERG, H. C. - Rose overlaid ivory. Roots, $\$ 1.50$. 
CITY OF TRENTON, D. - Color is a rich glowing tangerne with reverse crushed strawberry, a two-toned effect that is very attractve. Roots $\$ 2.00$.

EDNA FERBER, H. C. - Color is a glistening coral shading to old gold. Roots, $\$ 2.00$.

FORT MONMOUTH, H. C. - Color is a rich crimson maroon with shading of blueish violet at tips of petals and an excellent keeper as a cut flower. Roots, $\$ 5.00$.

FORT WASHINGTON, D. - A very deep maroon color. Roots, $\$ 1.50$.

FRANK MILLER, D. - Large, Massive Yellow; one of the best from California last season. Roots $\$ 6.00$.

GOLDEN SONNE (imported) True Cactus, Golden yellow to salmon. Roots, $\$ 2.00$.

GOVERNOR ALVAN T. FULLER, H. D. - Tyrian Rose Roots, \$3.00.

GRACE CURLING, D. - Lilac Pink and Rose. Roots, $\$ 7.50$.

HARRY MAYER, D. - Pale rosaline purple, reverse of petals veined wth a deeper shade. Roots $\$ 1.50$. IDA PERKINS, D - Clear white. A true decorative with very great substance. Roots, $\$ 1.50$. JANE COWL, D. - Bronze buff and salmon shades. Roots, $\$ 1.50$.

JERSEY'S MASTERPIECE, D. - Strawberry pink suffused gold. Roots, $\$ 2.00$.

JUDGE LEON McCORD, D. - Deepest shade of gold, with a revese of old rose. Roots, $\$ 4.00$.

KEMP'S VIOLET WONDER, D. - One of the best violet colored dahlias to date. Roots, $\$ 3.50$.

KATHLEEN NORRIS, D. - Without doubt the greatest of pink decorative dahlias. Roots, $\$ 6.50$. MRS. A. E. WHEELER, D. - Beautiful shade of purple. Roots. $\$ 2.00$.

MARIAN BROOMALL, H. C. - Pink and White. Roots, $\$ 1.50$.

MARMION, D.-Pure gold yellow suffused bronze; one of the best. Root, $\$ 1.00$.

IMRS. SHIRLEY SHAW, D. - Ox blood, red shaded maroon. Roots, $\$ 3.00$.

MRS. DR. JOHN PETTY, D. - Color is a combination of copper and yellow with reverse of red. Roots, $\$ 5.00$. 
MILDRED BROOKS HOOVER. D. - Color spinelRed, very unusual in a dahlia. Extra large blossoms on good stems. Roots, $\$ 5.00$.

MRS. ALFRED B. SEAL, D. - Undoubtedly the largest and finest pure, rich glowing old rose dahlia ever produced,-one that is different from any other. The flowers are huge in size and of great depth and substance and are held proudly erect above the fine tall plant. Roots, $\$ 7.50$.

MARTHA KEMP, H. D. - This is a very refined and a beatiful dahlia. The color is a warm buff, shading, to apricot-yellow. Roots, $\$ 4.00$.

MRS. EDWARD MILLAR, D. - A smart and pleasing real lemon yellow. Roots, $\$ 3.00$.

MISS RUTH GREENOUGH, D. - New pure white seedling of true decorative type, 7 to 9 inch blooms on good stemis. Good bloomer, excellent foliage. A decided addition to the dahlia garden. Roots, $\$ 2.50$.

PRIDE OF STRATFORD, D. - The coloring of this beautiful flower, is very striking, being a brilliant shade of cadmium orange, shading to orange yellow at base of petals - long strong stems. Roots $\$ 1.00$.

RISING MARS, H. C.-Pomegranate purple shading to deep red. Roots, $\$ 3.00$.

SPOTTSWOOD BEAUTY, D. - The color is a clear Chatenay pink, with a slight shading of lemon yellow at base of petals. Roots, $\$ 2.00$.

SANHICAN'S BEAUTY, D. - Rose shading to Bronze. Roots, $\$ 2.50$.

SANHICAN'S QUEEN, D. - Apricot and carmine rose. Roots, $\$ 2.50$.

SEAL'S CALIFORNIAN, D. - This large decorative dahlia is a bright golden yellow at the center, shading lighter toward the outer petals. Roots. $\$ 3.00$.

SIR JOHN CARLING, D. - Color is a royal purple of an entirely new shade. Roots, $\$ 4.00$.

SHIRLEY E. SHATTUCK, H. C. - Orchid lavender with a silver sheen. Roots, $\$ 1.50$. THE TELEGRAM, D. - Orange tipped white.
Roots, $\$ 1.00$.

WILLIAM H. HOGAN, D. - Garnet Red, white tips. Roots, $\$ 2.00$. 
WANDA MILLER, D. - Same color as "Our Country," has better stem and formation. Roots, $\$ 2.00$.

YANKEE KING, D. - A strong grower, color deep autumn tints, very attractive flower. Roots, $\$ 2.00$.

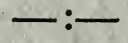

\section{Specials}

Any of the following varieties, $\$ 1.00$ each; 12 for $\$ 10.00$, as long as supply last: Margaret Woodrow Wilson, Becket's Oriental, Jersey's Beacon, Miss America, Mordella, Pop Stewart, Rose Fallon, Royal Beauty, Robert Scott, Rapallo, Jersey's Beauty.

Try one of my colections, well balanced as to colors and worth more than double price asked -from $\$ 3.00$ to $\$ 25.00$ per 12 .

\section{一:- \\ Green Plants}

A limited number of Green Plants of some of the newer varieties, for sale after May 1st, at Greenhouse, 25 French Street. Prices right.

Remittances may be made in the most convenient way when sent with order. plainly.

Be sure to write the name and address limited.

Order early as stock of some varieties is

All stock is field grown and not forced for blooms.

Usual Discount to Trade. 